\title{
WILDLIFE USE OF DOUGLAS-FIR DWARF MISTLETOE WITCHES’ BROOMS IN THE SOUTHWEST
}

\author{
Shaula J. Hedwall ${ }^{1}$ and Robert L. Mathiasen ${ }^{2,3}$
}

\begin{abstract}
Aвstract-We evaluated wildlife use of witches' brooms associated with infection by Douglas-fir dwarf mistletoe (Arceuthobium douglasii) in 6 mixed-conifer study areas in Arizona and 2 areas in New Mexico. We climbed 153 infected Douglas-firs (Pseudotsuga menziesii) and examined 706 witches' brooms for evidence of wildlife use. Even though we observed evidence of use by birds, most wildlife use was by small mammals, particularly red squirrels (Tamiasciurus hudsonicus). Red squirrels used witches' brooms for nesting, foraging, caching, and as latrines. Witches' brooms classified as Type II or III brooms, located close to the main bole with large platforms, and 5-10 m above the ground were the most frequently used by red squirrels.
\end{abstract}

Key words: Douglas-fir dwarf mistletoe, Arceuthobium douglasii, Douglas-fir, Pseudotsuga menziesii, red squirrel, Tamiasciurus hudsonicus, Southwest.

Douglas-fir dwarf mistletoe (Arceuthobium douglasii Engelm.) is a native, parasitic flowering plant that commonly occurs on Douglasfir (Pseudotsuga menziesii [Mirb.] Franco) throughout most of the western United States (Hawksworth and Wiens 1996, Hadfield et al. 2000). This mistletoe is the primary disease agent affecting Douglas-fir over most of its range, causing increased mortality and reduced growth rates of severely infected trees (Weir 1916, Pierce 1960, Mathiasen et al. 1990, Hawksworth and Wiens 1996). The abundance of Douglas-fir dwarf mistletoe has increased since the late 1800s due to fire suppression and selective harvesting practices (Hadfield et al. 2000). Fire suppression has allowed Douglas-fir to survive on millions of acres where it was once only a minor stand component. This has favored the spread and increase of Douglas-fir dwarf mistletoe. Selective harvesting has removed large-diameter Douglas-firs with little or no dwarf mistletoe while leaving large, severely infected or small, poor-quality infected trees. This harvesting practice has allowed the mistletoe to intensify within trees and to spread to neighboring trees over large areas (Hadfield et al. 2000). This situation is readily apparent in the Southwest where Douglas-fir dwarf mistletoe is common in all of the national forests (Jones 1974, Mathiasen et al. 1990, Hawksworth and Wiens 1996).

The most obvious symptom of infection associated with dwarf mistletoes, particularly Douglas-fir dwarf mistletoe, is abnormal masses of branches called witches' brooms (Hawksworth and Wiens 1996). Three types of witches' brooms (hereafter referred to as brooms) induced by Douglas-fir dwarf mistletoe have been described: Types I, II, and III (Tinnin and Knutson 1985). Type I brooms develop $\geq 1$ $\mathrm{m}$ from the main bole of the infected tree, and infected branches tend to droop. Type II brooms usually develop $\leq 1 \mathrm{~m}$ from the main bole and tend to grow upward. Type III brooms are formed by several adventitious branches that grow directly out of the main bole, again in an upward direction. Types II and III brooms can reach large sizes. Large brooms may form long drooping branches that hang down 2-3 m. Tinnin and Knutson (1985) and Parks et al. (1999) provide illustrations of the locations and structures of each broom type.

Many wildlife species use brooms for nesting, foraging, hiding, or resting sites (Hawksworth and Wiens 1996, Mathiasen 1996, Shaw et al. 2004). Of particular interest to wildlife biologists is that many raptors have been observed using brooms in the western United

${ }^{1}$ U.S. Fish and Wildlife Service, 323 Leroux, Flagstaff, AZ 86001.

${ }^{2}$ School of Forestry, Box 15018, Northern Arizona University, Flagstaff, AZ 86011.

${ }^{3}$ Corresponding author. E-mail: robert.mathiasen@nau.edu 
States (Hawksworth and Wiens 1996, Shaw et al. 2004). For example, the Northern Spotted Owl (Strix occidentalis caurina) and the Mexican Spotted Owl (Strix occidentalis lucida), both federally listed as threatened or endangered species, use brooms as nesting sites (Fletcher 1990, Forsman et al. 1990, Martin et al. 1992, Seamans and Gutiérrez 1995). However, few passerines or other birds have been observed using brooms (Hawksworth and Wiens 1996).

Mammals also use brooms, particularly squirrels (Hawksworth and Wiens 1996). For example, red squirrels (Tamiasciurus hudsonicus) frequently use brooms for nesting sites in east central Arizona (Vahle 1978), in northeastern Oregon (Parks et al. 1999), and in north central Washington (Tinnin and Forbes 1999).

Although several wildlife species use brooms in the Southwest, few studies have attempted to determine the species that most frequently use these brooms or the broom characteristics that are most important. Therefore, we initiated this study to obtain additional information on which birds and mammals commonly use Douglas-fir dwarf mistletoe brooms in mixed-conifer forests of the Southwest.

\section{STUdy Areas}

We selected 6 mixed-conifer stands in Arizona and 2 stands in New Mexico based on the presence and abundance of Douglas-fir dwarf mistletoe occurring over an area of at least 20 ha with infection in a variety of size classes. Four study areas (Little Springs, Schultz Creek, Lamar Haines, and Aubineau) were located on the San Francisco Peaks, Arizona (Coconino National Forest); 3 study areas (Alpine, Apache, and Horse Mesa) were located in the White Mountains in Arizona and New Mexico (Apache-Sitgreaves National Forest); and 1 study area (Jemez Springs) was located in the Jemez Mountains, New Mexico (Santa Fe National Forest; Fig. 1). All 8 study areas were located in mature, multistoried mixedconifer forests composed of various mixtures of Douglas-fir, ponderosa pine (Pinus ponderosa), and southwestern white pine (Pinus strobiformis Engelm.); Douglas-fir was always the dominant species. In some stands, we also found limited numbers of white fir (Abies concolor [Gord. \& Glend] Hildebr.), Engelmann spruce (Picea engelmannii Parry ex Engelm.), corkbark fir (Abies lasiocarpa [Hook.] Nutt. var. arizonica [Merriam] Lemm.), or aspen (Populus tremuloides Michx.).

Elevations of the study areas ranged from $2400 \mathrm{~m}$ to $2800 \mathrm{~m}$ and slopes ranged from $13 \%-45 \%$. None of the study areas had been disturbed by management activities or wildfire for at least 20 years prior to data collection, except for Horse Mesa, which had been thinned approximately 10 years prior to data collection. We estimated tree densities in the study areas in terms of basal area $\left(\mathrm{m}^{2} \cdot \mathrm{ha}^{-1}\right)$ by measuring the approximate tree density around sampled Douglas-firs. Mean basal areas ranged from 30 to $47 \mathrm{~m}^{2} \cdot \mathrm{ha}^{-1}$, but most study areas had mean basal areas $>40 \mathrm{~m}^{2} \cdot \mathrm{ha}^{-1}$.

\section{MethodS}

In 1998, at 3 of the study areas on the Coconino National Forest, dwarf mistletoeinfected Douglas-firs were selected using a square grid system of intersecting transects. At the Little Springs and Lamar Haines study areas, a $4 \times 4$ grid with transects placed $80 \mathrm{~m}$ apart was used to sample 16 points. At the Schultz Creek study area, a $5 \times 5$ grid was used that sampled 25 points because fewer climbable broomed trees grew in this area. At each study area, we climbed and inspected trees for evidence of wildlife use from September through November in 1998 and 1999. Grid systems were located using a random starting point at 1 corner of the study area. Transects were run in directions ensuring that all sampling points would fall within the designated study area boundaries. At each grid point, we climbed the closest Douglas-fir with at least 1 broom in each of 3 diameter-atbreast-height classes (dbh, measured at $1.4 \mathrm{~m}$ above the ground): $10-25 \mathrm{~cm}, 26-40 \mathrm{~cm}$, and $>40 \mathrm{~cm}$. Only Douglas-firs with brooms and within $40 \mathrm{~m}$ of the sampling point were selected. Therefore, not all diameter classes were represented at every sampling point. Sample sizes by diameter class were 25 trees in the 10-25-cm class, 29 trees in the 26-40cm class, and 24 trees in the $>40-\mathrm{cm}$ class. Sample sizes by study site were 30 trees at Lamar Haines, 25 trees at Little Springs, and 23 trees at Schultz Creek.

In 1999, at 5 study areas (Aubineau, Apache, Alpine, Horse Mesa, and Jemez Springs), a line transect $400 \mathrm{~m}$ to $560 \mathrm{~m}$ in length was used to 


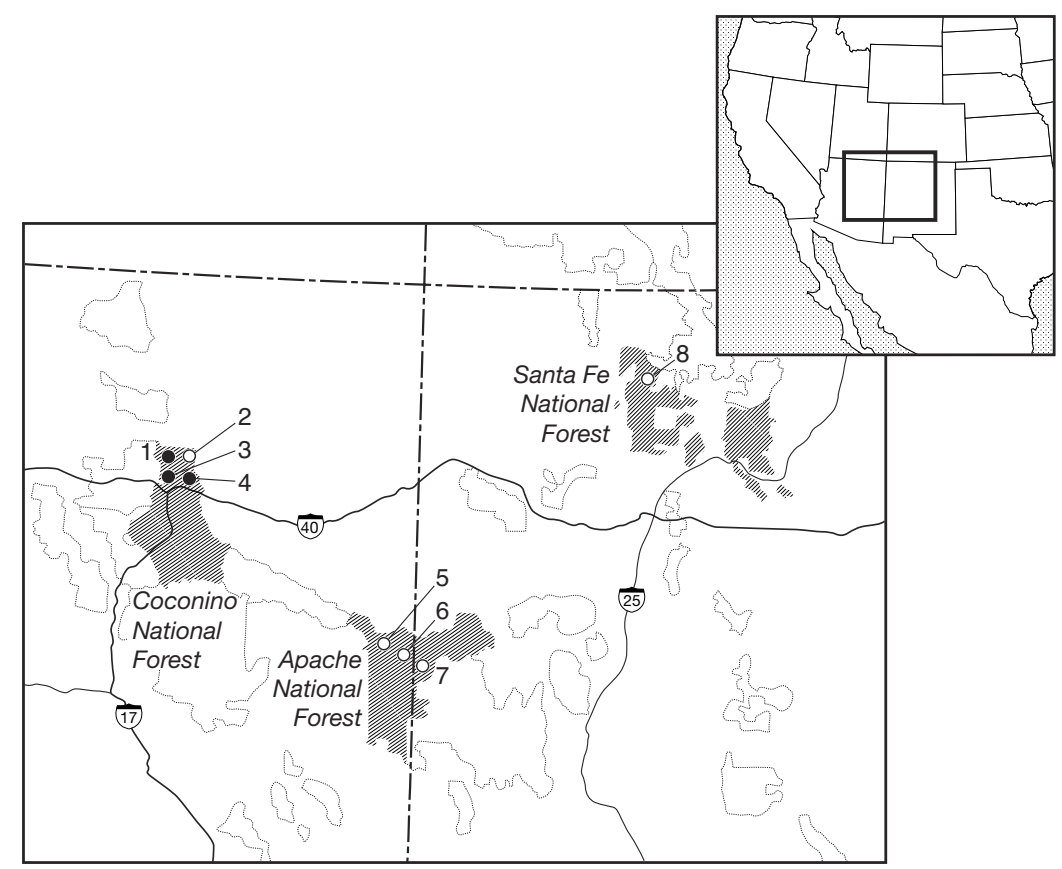

Fig. 1. Approximate locations of 8 study areas sampled in Arizona and New Mexico: (1) Little Springs, (2) Aubineau, (3) Lamar Haines, (4) Schultz Creek, (5) Apache, (6) Alpine, (7) Horse Mesa, and (8) Jemez Springs. Open circles represent study areas sampled using a grid system of 16-25 sample points, and dark circles represent study areas sampled using a line transect with 5-7 sample points spaced at 80-m intervals.

systematically sample broomed Douglas-firs. We discovered in 1998 that use of the grid system was time consuming, so we modified the sampling system in 1999 so that we could sample as many additional study areas as possible in other parts of the Southwest. Transects were started from a randomly selected point and run in a direction that would ensure that each transect stayed within the study area boundaries. Five to 7 sample points were established along transects at 80-m intervals, depending on the availability of climbable, broomed Douglas-firs. Fifteen trees were sampled along each transect in the 5 study areas from June 1999 through August 1999 (i.e., $n=75$ trees).

We climbed trees by using climbing spurs or ladders. All accessible brooms in each tree were inspected for evidence of wildlife use, and, whenever possible, the bird or mammal species using the brooms was identified. Scats, constructed nests, and evidence of foraging such as cone cores, cone scales, or seed casings were classified as evidence of mammalian use in a broom. Bird nests, whitewash, or pellets were considered evidence of avian use. If cone cores, scales, or whole cones were observed, then the broom was classified as a foraging/feeding site. Brooms that had scat, fur, or feathers and that did not appear to be frequently used were classified as resting sites. Measurements recorded for brooms included height above the ground (nearest $0.1 \mathrm{~m}$ ), aspect on the tree (degrees), and distance from the main bole of the tree (nearest $0.1 \mathrm{~m}$ ). We also recorded the broom type (I, II, or III; Tinnin and Knutson 1985), approximate volume of the broom $\left(\mathrm{m}^{3}\right)$, and platform size when present $\left(\mathrm{cm}^{2}\right.$; Parks et al. 1999). Within the 8 study areas, 153 trees and 706 brooms were examined for evidence of wildlife use.

\section{Results}

Wildlife use of brooms was prevalent at each of the study areas sampled. We found evidence of wildlife use in $100 \%$ of trees examined at the Little Springs, Schultz Creek, Horse Mesa, and Jemez Springs study areas; in over $90 \%$ of the trees at the Lamar Haines and Apache study areas; and in $80 \%$ of trees at 
the Aubineau and Alpine study areas. A total of $189(27 \%)$ of the 706 brooms we examined had no evidence of wildlife use.

We observed use of brooms by small mammals for nesting, foraging/feeding, and resting. A total of $362(51 \%)$ of 706 brooms examined contained sign of small mammal foraging and caching (Table 1). A total of 111 (16\%) brooms contained grass nests of red squirrels. Another 30 brooms $(4 \%)$ contained sign indicative of use as resting sites or latrines for mammals. Evidence of mammal use dominated in the brooms we examined, and sign of red squirrels was found in more brooms than sign of any other species. Red squirrels used brooms for nesting, foraging, caching, and latrine sites.

All broom types were used for nesting by red squirrels: $45 \%$ of nests were in Type II brooms, $34 \%$ in Type III brooms, and $21 \%$ in Type I brooms (Table 1). The majority of red squirrel nests were found at heights between $4.5 \mathrm{~m}$ and $10 \mathrm{~m}$, but several nests $(35 \%)$ were found $>10 \mathrm{~m}$ high. Nests were located no more than $3.5 \mathrm{~m}$ from the main bole of the trees. Broom size and platform size varied a great deal for the 111 brooms used by red squirrels for nesting (Table 2).

Woodrat dens were found at 2 sites (Alpine and Apache), but woodrats were also observed using brooms at the Lamar Haines, Little Springs, and Schultz Creek study areas. All 6 woodrat dens were in Type II or III brooms (Table 1) and were located next to the main bole of the tree. Brooms used for woodrat dens had comparatively large volumes and platform sizes when compared to those used by red squirrels (Table 2). We were unable to identify the species of woodrat that constructed the dens.

Twenty-eight brooms were categorized as mammal resting sites (Table 1). Ninety-three percent of these brooms were Type II or III brooms. These brooms contained mostly scats of red squirrels or foraging debris such as conifer cones, cone cores, seeds, or clipped branches. Brooms were also used as foraging and caching sites by gray-collared chipmunks (Tamias cinereicollis) and deer mice (Peromyscus maniculatus) based on presence of pellets and fur. Porcupine (Erethizon dorsatum) pellets and foraging debris were found in 2 brooms. One Type II broom containing raccoon (Procyon lotor) scat was categorized as a resting site.
TABLE 1 . Use of the 3 broom types by mammals in Arizona and New Mexico. We examined 507 Douglas-fir dwarf mistletoe witches' brooms.

\begin{tabular}{lrrrr}
\hline & \multicolumn{3}{c}{ Broom type } & \\
\cline { 2 - 4 } Mammal use & \multicolumn{1}{c}{ I } & \multicolumn{1}{c}{ II } & III & Total \\
\hline Red squirrel nests & 23 & 50 & 38 & 111 \\
Woodrat nests & 0 & 3 & 3 & 6 \\
Foraging/feeding sites & 133 & 170 & 59 & 362 \\
Resting sites & 2 & 18 & 8 & 28 \\
ToTAL & 158 & 241 & 108 & 507 \\
\hline
\end{tabular}

Avian sign was not as prevalent in brooms as mammalian sign. Only 8 nests of 6 avian species were found in brooms: Sharp-shinned Hawk (Accipiter striatus; 1 nest), Common Raven (Corvus corax; 2 nests), American Robin (Turdus migratorius; 1 nest), Hermit Thrush (Catharus guttatus; 2 nests), Western Tanager (Piranga ludoviciana; 1 nest), and an unidentified passerine (1 nest). All nests were located within $1 \mathrm{~m}$ of the main bole of the tree but were located at heights varying from $1.5 \mathrm{~m}$ (Hermit Thrush nest) to as high as $20.1 \mathrm{~m}$ (Common Raven nest). Avian roost sign was found in 17 brooms: 6 in Type I, 6 in Type II, and 5 in Type III brooms. Almost half of these brooms (47\%) also contained evidence of use by small mammals. Some of the roosting sites had large amounts of whitewash suggesting that raptors or other large birds were using the brooms.

\section{Discussion}

In the majority of brooms we examined in Arizona and New Mexico, we found evidence of use by a diversity of wildlife species. The high incidence $(75 \%)$ of small mammal sign found in brooms indicates that these animals, particularly red squirrels, commonly use brooms in the Southwest. Small mammal use was also the most common use of brooms found by Parks et al. (1999) in northeastern Oregon, where $51 \%$ of 261 brooms were used as foraging sites and $18 \%$ were used as nesting sites. The majority of mammal nests we found in brooms were constructed by red squirrels, but woodrats (probably the Mexican woodrat, Neotoma mexicana) also used these brooms for nesting. Parks et al. (1999) reported a similar use pattern in northeastern Oregon where small mammal nests in brooms were constructed by red squirrels, chipmunks (Tamias spp.), and 
TABLE 2. Characteristics of Douglas-fir dwarf mistletoe witches' brooms in Arizona and New Mexico that were used by mammals.

\begin{tabular}{|c|c|c|c|c|c|c|c|c|c|}
\hline \multirow[b]{2}{*}{ Mammal use } & \multirow[b]{2}{*}{$n$} & \multicolumn{2}{|c|}{$\begin{array}{c}\text { Broom } \\
\text { height }(\mathrm{m})\end{array}$} & \multicolumn{2}{|c|}{$\begin{array}{c}\text { Distance to } \\
\text { main bole (m) } \\
\end{array}$} & \multicolumn{2}{|c|}{$\begin{array}{c}\text { Broom } \\
\text { volume }\left(\mathrm{m}^{3}\right)\end{array}$} & \multicolumn{2}{|c|}{$\begin{array}{c}\text { Platform } \\
\text { size }\left(\mathrm{cm}^{2}\right)\end{array}$} \\
\hline & & $\bar{x}$ & Range & $\bar{x}$ & Range & $\bar{x}$ & Range & $\bar{x}$ & Range \\
\hline Red squirrel nests & 111 & 8.9 & $1.6-23$ & 0.4 & $0-3.0$ & 35 & $0.1-840$ & 780 & $0-12,500$ \\
\hline Woodrat nests & 6 & 6.3 & $1.5-11.8$ & 0.3 & $0-1.0$ & 119 & $48-225$ & 2633 & $50-5400$ \\
\hline Foraging/caching & 362 & 8.9 & $0.1-22.9$ & 0.6 & $0-4.0$ & 16 & $0.1-730$ & 297 & $10-8000$ \\
\hline Resting sites & 28 & 7.7 & $1.4-16.5$ & 0.3 & $0-1.5$ & 38 & $0.3-336$ & 784 & $10-8000$ \\
\hline
\end{tabular}

northern flying squirrels (Glaucomys sabrinus). Red squirrels and northern flying squirrels also commonly use brooms as nesting sites in northeastern Oregon (Bull et al. 2004).

The classification system developed by Tinnin and Knutson (1985) to characterize brooms (Types I-III) for the Pacific Northwest works well in the Southwest. We were able to easily classify all of the brooms we examined. The type of broom is important because most use by red squirrels reported by other investigators has been in Type II or III brooms (Parks et al. 1999, Tinnin and Forbes 1999, Bull et al. 2004).

Our study and several others (Vahle 1978, Patton and Vahle 1986, Parks et al. 1999, Tinnin and Forbes 1999, Bull et al. 2004) indicated that small mammals, particularly red squirrels, frequently use brooms for nesting sites and that the characteristics and locations of the brooms used were similar. The small mammal nests we found occurred more often in Type II brooms, but Type I and III brooms were also commonly used. Parks et al. (1999) found that most small mammal nests were in Type II and III brooms. However, they only found 2 small mammal nests in Type I brooms, whereas we found red squirrel nests in 23 Type I brooms. Tinnin and Forbes (1999) reported that the red squirrels nests they found in brooms in north central Washington were all in Type II or III brooms.

Even though Vahle (1978) reported that $28 \%$ of the red squirrel nests he located in east central Arizona were in brooms, he did not characterize the brooms themselves. However, he reported that the red squirrel nests he examined were all constructed within $3 \mathrm{~m}$ of the main bole and 4.5-10 $\mathrm{m}$ above the ground. Most red squirrel nests we found in brooms were also located within $3 \mathrm{~m}$ of the main bole and between $4.5 \mathrm{~m}$ and $10 \mathrm{~m}$ above the ground.
Tinnin and Forbes (1999) and Bull et al. (2004) reported similar nest heights for the red squirrel nests they found in brooms. We also found that large brooms with some type of platform were more frequently used by small mammals for nesting sites than were small brooms. Parks et al. (1999) reported similar findings for the small mammal nesting sites they found in brooms, as did Tinnin and Forbes (1999) for red squirrels. Bull et al. (2004) reported that half of the rest sites of arboreal squirrels were in dwarf mistletoe witches' brooms and that when brooms were removed from their study areas, the abundance of northern flying squirrels decreased. After broom removal the abundance of red squirrels increased in these study areas, possibly because of increased food resources and less competition from northern flying squirrels. Bull et al. (2004) concluded that dwarf mistletoe witches' brooms are important to arboreal squirrels for resting and nesting sites but that brooms are less important to red squirrels than they are to northern flying squirrels. Although specific quantitative experiments were not conducted in this study, the frequent use of brooms by red squirrels for nesting and resting sites suggests that brooms are probably important resources for red squirrels in the Southwest.

Of the 8 bird nests we found in brooms (representing only 1\% of the brooms examined), all were within $1 \mathrm{~m}$ of the main bole and all but 1 of them was found in a Type II broom. In contrast, Parks et al. (1999) did not find any bird nests in the brooms they examined in northeastern Oregon. They hypothesized that this was due to the high incidence of mammalian use. The high use of brooms by red squirrels in the Southwest may also account for the infrequent use of brooms by birds, because red squirrels are well-known predators of passerine eggs and nestlings (Welty 1975). 
Although several bird species have been reported to nest in brooms associated with dwarf mistletoe infection in other tree species (Hawksworth and Wiens 1996), to our knowledge, we are the first to report use of Douglasfir dwarf mistletoe witches' brooms as nest sites by the bird species listed above. Further research is needed throughout the western United States to describe use of brooms by birds for nesting, roosting, foraging, and hiding sites. This is particularly important because many raptors, including Spotted Owls, have been reported to use brooms for nesting sites in the western United States (Hawksworth and Wiens 1996).

\section{ACKNOWLEDGMENTS}

This study was funded by the Mission Research Program, School of Forestry, Northern Arizona University, Flagstaff, and the Pacific Northwest Research Station, USDA Forest Service, La Grande, Oregon. Drs. Carol Chambers (Northern Arizona University), Steve Rosenstock (Arizona Department of Fish and Game), and Catherine Parks (Pacific Northwest Research Station) provided valuable advice and assistance related to this study. We appreciate the invaluable assistance of T. Hedwall, B. Holmquist, D. Huebner, T. Grubb, R. Lopez, and M. Fairweather with data collection in the field. Several individuals provided critical reviews of previous versions of the manuscript, and their comments have been adopted whenever possible.

\section{Literature Cited}

Bull, E.L., T.W. Heater, and E.L. Youngblood. 2004. Arboreal squirrel response to silvicultural treatments for dwarf mistletoe in northeastern Oregon. Western Journal of Applied Forestry 19:133-141.

FleTCHER, K.W. 1990. Habitats used, abundance and distribution of the Mexican Spotted Owl, Strix occidentalis lucida, on National Forest System lands. USDA Forest Service, Southwestern Region, Albuquerque, NM.

Forsman, E.D., S.C. Sovern, M. Taylor, D.N. Rolph, and K.J. Maurice. 1990. Home range and habitat of Northern Spotted Owls on the east slope of the Cascade Mountains, Washington. Northwest Environment Journal 6:430-431.

Hadfield, J.S., R.L. Mathiasen, and F.G. Hawksworth. 2000. Douglas-fir dwarf mistletoe. Forest Insect and Disease Leaflet 54, USDA Forest Service, Forest Insects and Diseases, Pacific Northwest Region, Portland, OR.
Hawksworth, F.G., and D. WiEns. 1996. Dwarf mistletoes: biology, pathology, and systematics. Agriculture Handbook 709, USDA Forest Service, Washington, DC.

Jones, J.R. 1974. Silviculture of Southwestern mixed conifer forests: the status of our knowledge. Research Paper RM-122, USDA Forest Service, Rocky Mountain Research Station, Fort Collins, CO.

Martin, S.K., J.S. BeatTy, and F.G. Hawksworth. 1992. Douglas-fir dwarf mistletoe brooms and Spotted Owl nesting habitat: eastern Cascade Range, Washington. Pages 77-79 in S. Frankel, technical editor, Proceedings of the 40th Annual Western International Forest Disease Work Conference, USDA Forest Service, Pacific Southwest Research Station, Berkeley, CA.

Mathiasen, R.L. 1996. Dwarf mistletoes in forest canopies. Northwest Science 70:61-71.

Mathiasen, R.L., F.G. Hawksworth, and C.B. EdminSTER. 1990. Effects of dwarf mistletoe on growth and mortality of Douglas-fir in the Southwest. Great Basin Naturalist 50:173-179.

Parks, C.G., E.L. Bull, R.O. Tinnin, J.F. Shepherd, and K.A. Blumton. 1999. Wildlife use of dwarf mistletoe brooms in Douglas-fir in northeast Oregon. Western Journal of Applied Forestry 14:100-105.

Patton, D.R., And J.R. VAhLE. 1986. Cache and nest characteristics of the red squirrel in an Arizona mixed conifer forest. Western Journal of Applied Forestry 1:48-51.

Pierce, W.R. 1960. Dwarf mistletoe and its effect upon the larch and Douglas-fir of western Montana. Bulletin 10, School of Forestry, Montana State University, Bozeman.

Seamans, M.E., And R.J. Gutierrez. 1995. Breeding habitat of the Mexican Spotted Owl in the Tularosa Mountains, New Mexico. Condor 97:944-952.

Shaw, D.C., D.A. Watson, and R.L. Mathiasen. 2004. Comparison of dwarf mistletoe (Arceuthobium spp., Viscaceae) in the western United States with mistletoes (Amyema spp., Loranthaceae) in Australia-ecological analogs and reciprocal models for ecosystem management. Australian Journal of Botany 52:481498.

Tinnin, R.O., And R.B. Forbes. 1999. Red squirrel nests in witches' brooms in Douglas-fir trees. Northwestern Naturalist 80:17-21.

Tinnin, R.O., AND D.M. Knutson. 1985. How to identify brooms in Douglas-fir caused by dwarf mistletoe. Research Note PNW-426, USDA Forest Service, Pacific Northwest Research Station, Portland, OR.

VAHLE, J.R. 1978. Red squirrel use of southwestern mixed coniferous habitat. Master's thesis, Arizona State University, Tempe.

WEIR, J.R. 1916. Mistletoe injury to conifers in the Northwest. U.S. Department of Agriculture Bulletin 360, Washington, DC.

WeLty, J.C. 1975. The life of birds. W.B. Saunders, New York.

Received 8 September 2005 Accepted 28 March 2006 